\title{
Greenhouse Gas Emission Fluxes from Hummocky and Hollow in the Peat Bog of Arak Lake Basin in 2020
}

\author{
Hang Cui ${ }^{1,2}$ \\ ${ }^{1}$ MOE Key Laboratory of Tibetan Plateau Land Surface Processes and Ecological Conservation, Qinghai Normal University, Xining, China \\ ${ }^{2}$ Qinghai Province Key Laboratory of Physical Geography and Environmental Process, College of Geographical Sciences, Qinghai Normal \\ University, Xining, China
}

Email address:

cuihang071987@163.com

\section{To cite this article:}

Hang Cui. Greenhouse Gas Emission Fluxes from Hummocky and Hollow in the Peat Bog of Arak Lake Basin in 2020. International Journal of Economy, Energy and Environment. Vol. 6, No. 5, 2021, pp. 104-109. doi: 10.11648/j.ijeee.20210605.14

Received: August 29, 2021; Accepted: September 11, 2021; Published: September 23, 2021

\begin{abstract}
The peat bogs on the Tibetan Plateau are an important source of carbon dioxide $\left(\mathrm{CO}_{2}\right)$ and methane $\left(\mathrm{CH}_{4}\right)$ in Chinese atmosphere. In order to study the effects of different micro-topography of peat bogs on $\mathrm{CO}_{2}$ and $\mathrm{CH}_{4}$ emission fluxes, the static box-meteorological chromatography method was used to determine the $\mathrm{CO}_{2}$ and $\mathrm{CH}_{4}$ emission fluxes of hummocky and hollow in the peat bogs in Arak Lake Basin from May to September in 2020. Our results showed that the peaks of $\mathrm{CO}_{2}$ and $\mathrm{CH}_{4}$ emission fluxes from hummocky and hollow all appeared in July, and the lowest values all appeared in May. The maximum $\mathrm{CO}_{2}$ emission fluxes of hummocky and hollow are $440.44 \mathrm{mg} \cdot \mathrm{m}^{-2} \cdot \mathrm{h}^{-1}$ and $198.20 \mathrm{mg} \cdot \mathrm{m}^{-2} \cdot \mathrm{h}^{-1}$, respectively, and the maximum $\mathrm{CH}_{4}$ emission fluxes are $2.62 \mathrm{mg} \cdot \mathrm{m}^{-2} \cdot \mathrm{h}^{-1}$ and $3.21 \mathrm{mg} \cdot \mathrm{m}^{-2} \cdot \mathrm{h}^{-1}$, respectively. The average $\mathrm{CO}_{2}$ emission flux during the growing season of hummocky $\left(368.79 \pm 54.70 \mathrm{mg} \cdot \mathrm{m}^{-2} \cdot \mathrm{h}^{-1}\right)$ was significantly higher than that of hollow $\left(165.96 \pm 20.19 \mathrm{mg} \cdot \mathrm{m}^{-2} \cdot \mathrm{h}^{-1}\right)(\mathrm{n}=5, \mathrm{p}=0.001)$, while the average $\mathrm{CH}_{4}$ emission flux of hummocky $\left(1.78 \pm 0.27 \mathrm{mg} \cdot \mathrm{m}^{-2} \cdot \mathrm{h}^{-1}\right)$ is significantly lower than that of hollow $(2.24 \pm 0.27$ $\left.\mathrm{mg} \cdot \mathrm{m}^{-2} \cdot \mathrm{h}^{-1}\right)(\mathrm{n}=5, \mathrm{p}=0.007)$. The $\mathrm{CO}_{2}$ emission flux of hummocky and hollow during the growing season is mainly affected by the $5 \mathrm{~cm}$ soil temperature, and the $\mathrm{CH}_{4}$ emission flux is mainly affected by the $5 \sim 20 \mathrm{~cm}$ soil temperature.
\end{abstract}

Keywords: Peat Bog, Hummocky, Hollow, $\mathrm{CO}_{2}, \mathrm{CH}_{4}$

\section{Introduction}

The carbon storage of peat bogs is $1 / 3$ of the global soil carbon storage, which is equivalent to $75 \%$ of the carbon storage in the atmosphere, and it is an important carbon sink [1]. Along with the respiration of peat bog animals, plants and microorganisms and the anaerobic biochemical reaction caused by the hypoxic environment, the peat bog will release a large amount of carbon dioxide $\left(\mathrm{CO}_{2}\right)$ and methane $\left(\mathrm{CH}_{4}\right)$, which is an important carbon source for the atmosphere [2]. $\mathrm{CO}_{2}$ and $\mathrm{CH}_{4}$ are the main greenhouse gases. Compared to the industrial revolution, the concentration of $\mathrm{CO}_{2}$ and $\mathrm{CH}_{4}$ in the atmosphere has increased to 1.35 times and 2.48 times respectively at present [3]. The results of the Fifth IPCC Assessment Report showed that the global average temperature in 2012 was $0.85^{\circ} \mathrm{C}$ higher than that in 1880 [4]. The increase in temperature causes the permafrost to degrade, and the exchange flux of greenhouse gases with the atmosphere of the peat bogs, which is associated with permafrost [5], will inevitably change.

China's peat bogs are mainly distributed in the northeast of China high latitudes and west of China high mountains. The distribution pattern is mainly affected by the freezing and thawing of the surface soil in the frozen soil area [5]. It has obvious latitude zonality (northeast of China high latitudes) and vertical zonality (Tibetan Plateau and adjacent mountains) [6]. At present, the domestic research on the greenhouse gas emission flux of peat bogs has obtained some research results [7-13]. However, for the vast peat bogs in China, especially for the Tibetan Plateau, current researches are still insufficient. The unique geographical location and altitude of the Tibetan Plateau make it a driver and amplifier of global climate change [14]. Under the background of global warming, the climate change in Tibetan Plateau is more intense than lower altitude areas. The ecological system of peat bogs in Tibetan Plateau will inevitably be more affected. Therefore, the exchange flux of greenhouse gases between the peat bogs on the Tibetan 
Plateau and the atmosphere is an important content of current research, and it is of great significance for understanding the carbon cycle of peat bogs under the background of global warming.

Previous studies have shown that there are differences in the emission fluxes of $\mathrm{CO}_{2}$ and $\mathrm{CH}_{4}$ between different micro-topography of peat bogs, which in turn makes the emission fluxes of $\mathrm{CO}_{2}$ and $\mathrm{CH}_{4}$ in the peat bog ecosystems spatially different. At present, the relevant research on the emission fluxes of $\mathrm{CO}_{2}$ and $\mathrm{CH}_{4}$ from different micro-topography of the peat bog ecosystem of the Tibetan Plateau has not been carried out in depth, and related work has been carried out only in some areas, such as the peat bog of Zoigê Plateau [15]. Therefore, in this paper, the hummocky and hollow in the peat bog of Arak Lake Basin is the research object, and static box-meteorological chromatography method was applied to determine the $\mathrm{CO}_{2}$ and $\mathrm{CH}_{4}$ emission fluxes of the hummocky and hollow in the study area during the growth season in 2020, which can provide basic data for accurately predicting the emission fluxes of $\mathrm{CO}_{2}$ and $\mathrm{CH}_{4}$ from peat bogs on the Tibetan Plateau.

\section{Materials and Methods}

\subsection{Study Area}

The Arak Lake Basin is located on the northeastern Tibetan Plateau and the southern Qaidam Basin, adjacent to Zaling Lake and Eling Lake in the source area of the Yellow River. The geographical coordinates are $96.91^{\circ} \sim 97.33^{\circ} \mathrm{E}$ and $35.53^{\circ} \sim 35.61^{\circ} \mathrm{N}$. The Arak Lake developed in the basin has a length of $9.1 \mathrm{~km}$ from east to west, a maximum width of 6.8 $\mathrm{km}$ from north to south, an area of $36.2 \mathrm{~km}^{2}$, a water level of $4094 \mathrm{~m}$, a catchment area of $1320 \mathrm{~km}^{2}$, and a water storage capacity of 490 million cubic meters [16]. The water of Arak Lake is mainly supplied by the snowmelt of Burhan Budai Shan and Buqing Shan, bedrock fissure water, and the rivers [16]. There are three main types of wetland in the study area: lakes, peat bogs and rivers, with a total area of $8442.80 \mathrm{hm}^{2}$, of which the area of peat bogs is $4,320.78 \mathrm{hm}^{2}$, accounting for $51.18 \%$ of the total wetland area, mainly distributed around the Ulan Wusu River. It is the most important wetland type in the basin [16]. The study area is mainly controlled by the Asian monsoon. The meteorological data from 1981 to 2010 at the Golmud Meteorological Station $\left(36.42^{\circ} \mathrm{N}, 94.9^{\circ} \mathrm{E}, 2809\right.$ $\mathrm{m}$ asl) on the north side showed that the annual average temperature and annual precipitation are $5.8^{\circ} \mathrm{C}$ and $45 \mathrm{~mm}$, respectively. The precipitation is mainly concentrated in May to September.

\subsection{Sampling Location Setting}

At the end of April in 2020, in the hummocky and hollow $\left(35.58^{\circ} \mathrm{N}, 97.28^{\circ} \mathrm{E}, 4117 \mathrm{~m}\right.$ asl) of Arak Lake Basin, three static boxes were placed to observe the $\mathrm{CO}_{2}$ and $\mathrm{CH}_{4}$ fluxes respectively. The spacing between the different boxes is $1 \sim 3$ $\mathrm{m}$. The static box is composed of a box body and a base welded by stainless steel materials. The specifications of the box body and the base are $40 \mathrm{~cm} \times 40 \mathrm{~cm} \times 30 \mathrm{~cm}$ and $40 \mathrm{~cm} \times 40$ $\mathrm{cm} \times 10 \mathrm{~cm}$ respectively. A $2 \mathrm{~cm} \times 2 \mathrm{~cm}$ water tank is welded around the top of the base. The bottom of the base is inserted into the soil, and the base is placed in the study area during the observation period. The surrounding and top of the box are wrapped by thermal insulation foam board. A thermometer of model TM-902C is installed in the box to measure the temperature of the box, and the box is equipped with a small fan of $10 \mathrm{~cm} \times 10 \mathrm{~cm}$ to mix the gas in the box, which can reduce errors.

\section{3. $\mathrm{CO}_{2}$ and $\mathrm{CH}_{4}$ Emission Flux Measurement}

The gas collection time is May 15, June 17, August 22, and September 23 in 2020. The gas is collected once a month, and the gas is collected every 2 hours from 6 to 18:00 on each collection day, and the plants on the ground are cut off before collecting gas using scissors. When sampling the gas in the box, the water tank on the top of the base is filled with water and the box body is buckled. The gas is drawn with a $100 \mathrm{ml}$ medical syringe every 10 minutes within 0 to 30 minutes, and $60 \mathrm{ml}$ of gas is collected each time. The greenhouse gas concentration of collected gas was measured by Agilent 7890B meteorological chromatograph, and the greenhouse gas flux was calculated using the formula proposed by Parish et al. [17]:

$$
F=\rho \times \frac{V}{A} \times \frac{P}{P_{0}} \times \frac{T_{0}}{T} \times \frac{d C_{t}}{d_{t}}
$$

Where $F$ is the emission flux of the gas $\left(\mathrm{mg} \cdot \mathrm{m}^{-2} \cdot \mathrm{h}^{-1}\right), \rho$ is the density of the gas in the standard state $(\mathrm{g} / \mathrm{L}), V$ is the volume of air in the sampling box $\left(\mathrm{m}^{3}\right)$, and $A$ is the area covered by the sampling box $\left(\mathrm{m}^{2}\right), P$ is the air pressure at the sampling point $(\mathrm{hPa}), P_{0}$ is the standard atmospheric pressure $(\mathrm{hPa}), T_{0}$ is the absolute temperature of the air in the standard state $(\mathrm{K})$, and $T$ is the absolute air in the sampling box when the gas is collected Temperature $(\mathrm{K}), d C_{t} / d_{t}$ is the rate of change of the concentration of the gas collected in the sampling box over time.

While collecting gas in the box, the soil temperature at the depths of $5 \mathrm{~cm}, 10 \mathrm{~cm}, 15 \mathrm{~cm}, 20 \mathrm{~cm}, 30 \mathrm{~cm}$ and $45 \mathrm{~cm}$ was measured using the handheld TZS-5X soil temperature meter. A ruler was used to measure the water level of the hummocky and hollow at the sampling point. The water level is a positive value when it is higher than the ground surface, and the water level is a negative value when it is lower than the ground surface.

\subsection{Biomass Measurement}

In the hummocky and hollow near the sampling point, three $50 \mathrm{~cm} \times 50 \mathrm{~cm}$ squares were set respectively to collect the above-ground plants with scissors, and then the above-ground biomass of the plants were measured. Roots with a diameter of $7 \mathrm{~cm}$ are used to measure the underground biomass. Drill a 30 $\mathrm{cm}$ soil layer in the sample square where the vegetation has been cut down, and wash it with clean water, then put it in an envelope to dry it in an oven at $65^{\circ} \mathrm{C}$, and then weigh it as the plant underground biomass. 


\subsection{Statistical Analysis}

The processing of the data collected and the drawing of the graphs in this article were all carried out in the Excel 2010 version, and the paired $t$ test and independent sample $t$ test were completed in SPSS 21.0.

\section{Results and Analysis}

\subsection{Soil Temperature and Water Level in Hummocky and Hollow}

The soil temperature in the growing season of hummocky and hollow gradually decreases with the increase of soil depth. At the same soil depth, the soil temperature of hummocky is higher than that of hollow (Figure 1). At soil depths of $5 \mathrm{~cm}, 10 \mathrm{~cm}, 15 \mathrm{~cm}, 20 \mathrm{~cm}, 30 \mathrm{~cm}$, and $45 \mathrm{~cm}$, the average soil temperature during the growing season of the hummocky is $8.5^{\circ} \mathrm{C}, 8.3^{\circ} \mathrm{C}, 8.3^{\circ} \mathrm{C}, 9^{\circ} \mathrm{C}, 7.7$ and $7.1^{\circ} \mathrm{C}$, respectively, and the average soil temperature in the growing season of the hollow is $7.1^{\circ} \mathrm{C}, 7^{\circ} \mathrm{C}, 7.8^{\circ} \mathrm{C}, 8.2^{\circ} \mathrm{C}$, $7^{\circ} \mathrm{C}$ and $6.2^{\circ} \mathrm{C}$, respectively. The average water level in the growing season of the hummocky is $-9.5 \mathrm{~cm}$, and the average water level in the growing season of the hollow is 0.7 (Figure 2).
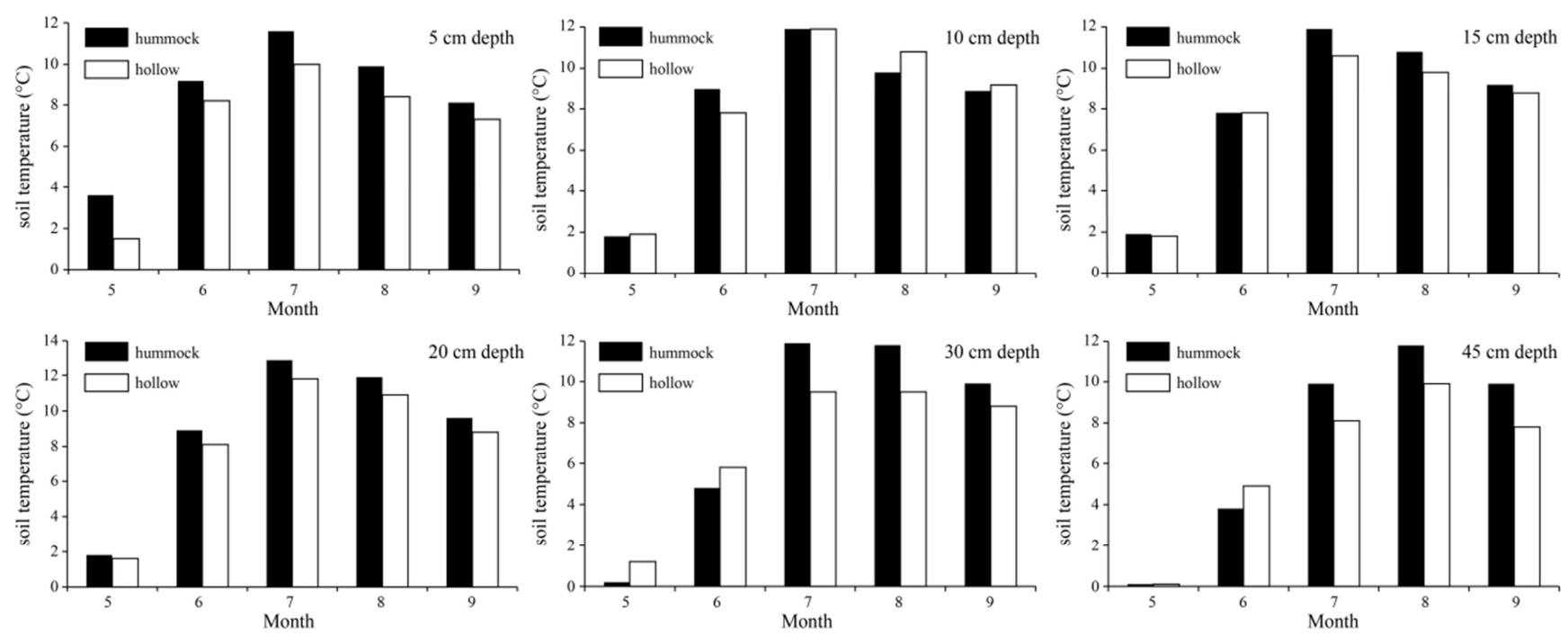

Figure 1. The soil temperatures at different depths in sampling months.

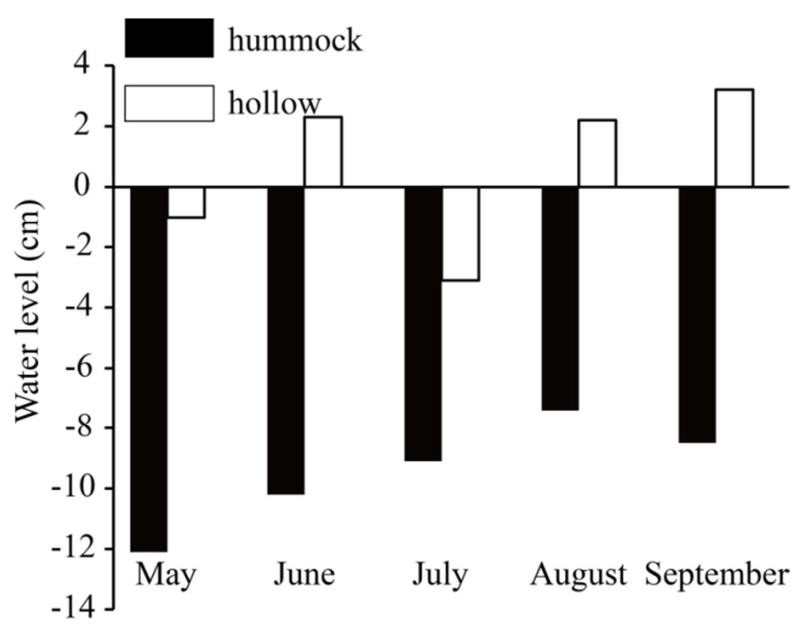

Figure 2. The water tables of fen in sampling months.

\subsection{The Biomass of Hummocky and Hollow}

The aboveground biomass of hummocky and hollow was $(123.44 \pm 21.23) \mathrm{g} / \mathrm{m}^{2}$ and $(98.22 \pm 17.21) \mathrm{g} / \mathrm{m}^{2}$, and the underground biomass was $(3215.21 \pm 783.32) \mathrm{g} / \mathrm{m}^{2}$ and $(2623.35 \pm 321.21) \mathrm{g} / \mathrm{m}^{2}$, respectively. The aboveground and underground biomass of the hollow were lower than that of the hummocky, but the difference between them is not significant $(n=3, p>0.05)$.

\section{3. $\mathrm{CO}_{2}$ and $\mathrm{CH}_{4}$ Emission Flux of Hummocky and Hollow}

The average $\mathrm{CO}_{2}$ emission flux during the growing season of the hummocky was $368.79 \pm 54.70 \mathrm{mg} \cdot \mathrm{m}^{-2} \cdot \mathrm{h}^{-1}$. The highest $\mathrm{CO}_{2}$ emission flux $\left(440.44 \mathrm{mg} \cdot \mathrm{m}^{-2} \cdot \mathrm{h}^{-1}\right)$ was in July, and the $\mathrm{CO}_{2}$ emission flux in May $\left(300.21 \mathrm{mg} \cdot \mathrm{m}^{-2} \cdot \mathrm{h}^{-1}\right)$ was the lowest (Figure 3); the average $\mathrm{CO}_{2}$ emission flux of the hollow during the growing season was $165.96 \pm 20.19 \mathrm{mg} \cdot \mathrm{m}^{-2} \cdot \mathrm{h}^{-1}$, which was lower than that of the hummocky and the difference of them was significant $(n=5, p=0.001)$. The $\mathrm{CO}_{2}$ emission flux of hollow in the same month is lower than that of hummocky. The highest value appeared in July $\left(198.20 \mathrm{mg} \cdot \mathrm{m}^{-2} \cdot \mathrm{h}^{-1}\right)$, and the lowest value appeared in May $\left(135.09 \mathrm{mg} \cdot \mathrm{m}^{-2} \cdot \mathrm{h}^{-1}\right.$ ) (Figure 3).

The average $\mathrm{CH}_{4}$ emission flux during the growing season of the hummocky was $1.78 \pm 0.27 \mathrm{mg} \cdot \mathrm{m}^{-2} \cdot \mathrm{h}^{-1}$. The highest $\mathrm{CH}_{4}$ emission flux $\left(2.62 \mathrm{mg} \cdot \mathrm{m}^{-2} \cdot \mathrm{h}^{-1}\right)$ was in July, and the lowest $\mathrm{CH}_{4}$ emission flux $\left(1.11 \mathrm{mg} \cdot \mathrm{m}^{-2} \cdot \mathrm{h}^{-1}\right)$ was in May (Figure 3); the average $\mathrm{CH}_{4}$ emission flux during the growing season of hollow was $2.24 \pm 0.27 \mathrm{mg} \cdot \mathrm{m}^{-2} \cdot \mathrm{h}^{-1}$, which is lower than that of hummocky. The difference of them was significant $(n=5$, $p=0.007$ ). The $\mathrm{CH}_{4}$ emission flux of hollow in the same month was higher than that of hummocky. The highest value of $\mathrm{CH}_{4}$ emission flux appeared in July $\left(3.21 \mathrm{mg} \cdot \mathrm{m}^{-2} \cdot \mathrm{h}^{-1}\right)$, and the lowest value appeared in May $\left(1.25 \mathrm{mg} \cdot \mathrm{m}^{-2} \cdot \mathrm{h}^{-1}\right)$ (Figure 3$)$. 

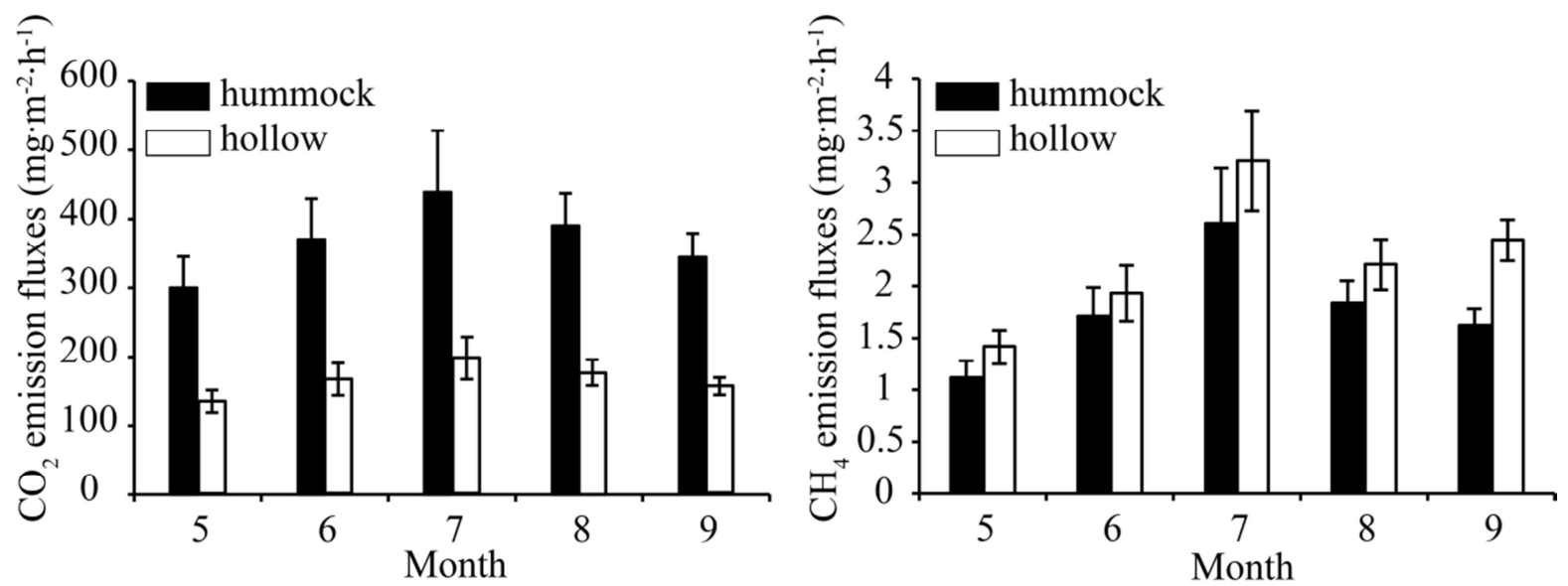

Figure 3. The $\mathrm{CO}_{2}$ and $\mathrm{CH}_{4}$ fluxes observed from hummock and hollow.

\subsection{Relationship Between $\mathrm{CO}_{2}$ and $\mathrm{CH}_{4}$ Emission Fluxes and Soil Temperature in Hummocky and Hollow}

The relationship between the emission flux of $\mathrm{CO}_{2}$ and $\mathrm{CH}_{4}$ and soil temperature was expressed by the parameter of soil temperature sensitivity $\left(Q_{10}\right)$ (Tongchuan et al., 2010), and its calculation formula is:

$$
\mathrm{Q}_{10}=\mathrm{e}^{10 \mathrm{~b}}
$$

where $b$ is the temperature reflection coefficient. The $b$ value can be obtained by fitting the emission flux of $\mathrm{CO}_{2}$ and $\mathrm{CH}_{4}$ to the soil temperature (Tong et al., 2010):

$$
\mathrm{F}=\mathrm{a} \times \mathrm{e}^{\mathrm{b} \times \mathrm{t}}
$$

where $F$ is the emission flux of $\mathrm{CO}_{2}$ and $\mathrm{CH}_{4}\left(\mathrm{mg} \cdot \mathrm{m}^{-2} \cdot \mathrm{h}^{-1}\right), t$ is the soil temperature $\left({ }^{\circ} \mathrm{C}\right)$, and $a$ is the emission flux of $\mathrm{CO}_{2}$ and $\mathrm{CH}_{4}\left(\mathrm{mg} \cdot \mathrm{m}^{-2} \cdot \mathrm{h}^{-1}\right)$ when the soil temperature is $0^{\circ} \mathrm{C}$.

Based on the Pearson correlation analysis method, the $\mathrm{CO}_{2}$ emission flux during the growing season of hummocky was significantly positively correlated with the soil temperature of $5 \sim 20 \mathrm{~cm}$, and the $\mathrm{CO}_{2}$ emission flux during the growing season of hollow was significantly positively correlated with the soil temperature of $5 \mathrm{~cm}$ (Table 1). After transforming the $\mathrm{CH}_{4}$ emission flux during the growing season of hummocky and hollow into a logarithmic value with a base of 10 , the $\mathrm{CH}_{4}$ emission flux during the growing season of hummocky was significantly positively correlated with the soil temperature of 5 20 cm, and the $\mathrm{CH}_{4}$ emission flux during the growing season of hollow was significantly positively correlated with the soil temperature of $5 \sim 30 \mathrm{~cm}$ (Table 1). Based on equation (2) and (3), the fitting relationship between the emission flux of $\mathrm{CO}_{2}$ and $\mathrm{CH}_{4}$ from hummocky and hollow and soil temperature, and the soil temperature sensitivity index $\mathrm{Q}_{10}$ were calculated (Table 3). The results showed that the $Q_{10}$ of the emission of $\mathrm{CO}_{2}$ and $\mathrm{CH}_{4}$ from hollow was greater than that of the hummocky, and the $Q_{10}$ of the $\mathrm{CH}_{4}$ emission flux of the hummocky and hollow was greater than the $Q_{10}$ of $\mathrm{CO}_{2}$ emission flux.

\begin{tabular}{|c|c|c|c|c|}
\hline Microtopography & variable & Variable range $\left({ }^{\circ} \mathrm{C}\right)$ & Correlation coefficient $r$ & $p$ \\
\hline \multirow{4}{*}{ hummocky } & soil temperature of $5 \mathrm{~cm}$ & $3.6 \sim 11.6$ & 0.95 & 0.013 \\
\hline & soil temperature of $10 \mathrm{~cm}$ & $1.8 \sim 11.9$ & 0.9 & 0.037 \\
\hline & soil temperature of $15 \mathrm{~cm}$ & $1.9 \sim 11.9$ & 0.89 & 0.046 \\
\hline & soil temperature of $20 \mathrm{~cm}$ & $1.8 \sim 12.9$ & 0.9 & 0.039 \\
\hline hollow & soil temperature of $5 \mathrm{~cm}$ & $1.5 \sim 10$ & 0.9 & 0.038 \\
\hline
\end{tabular}

Table 1. Correlation coefficients between $\mathrm{CO}_{2}$ emission flux and soil temperatures

Table 2. Correlation coefficients between the common logarithm of $\mathrm{CH}_{4}$ flux and soil temperatures.

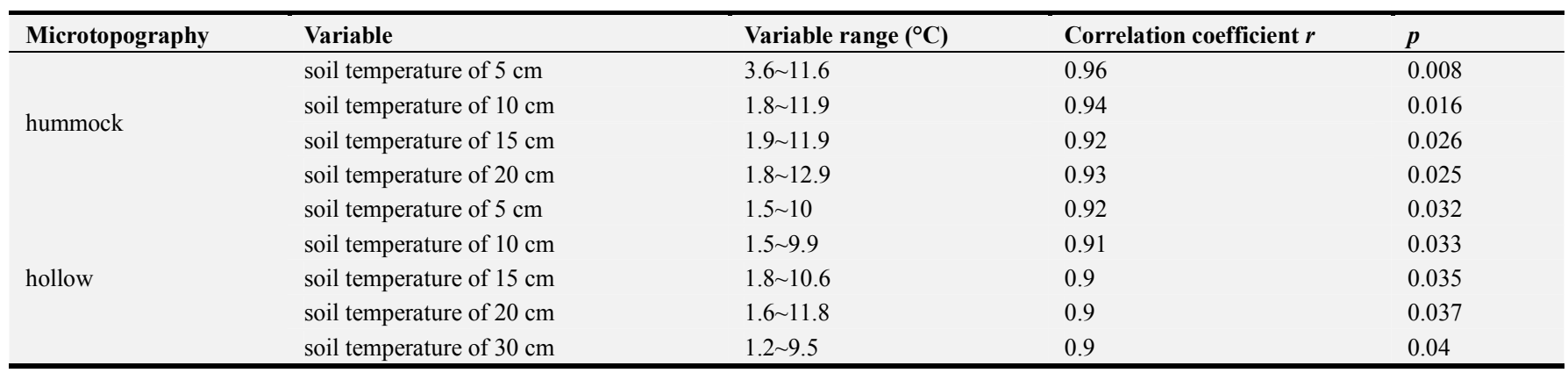


Table 3. The exponential relationship between $\mathrm{CO}_{2}$ and $\mathrm{CH}_{4}$ emission fluxes from hummock and hollow and soil temperatures, and soil temperature quotient.

\begin{tabular}{|c|c|c|c|c|c|c|}
\hline Soil depth & & $5 \mathrm{~cm}$ & $10 \mathrm{~cm}$ & $15 \mathrm{~cm}$ & $20 \mathrm{~cm}$ & $30 \mathrm{~cm}$ \\
\hline \multirow{6}{*}{$\mathrm{CO}_{2}$} & Relation & $F=247.4 \mathrm{e}^{0.036 t}$ & $F=274.57 \mathrm{e}^{0.035 t}$ & $F=277.56 \mathrm{e}^{0.033 t}$ & $F=278.37 \mathrm{e}^{0.03 t}$ & $F=307.23 \mathrm{e}^{0.023 t}$ \\
\hline & $\mathrm{R}^{2}$ & 0.94 & 0.85 & 0.81 & 0.84 & 0.64 \\
\hline & $\mathrm{Q}_{10}$ & 1.44 & 1.41 & 1.39 & 1.35 & 1.25 \\
\hline & Relation & $F=123.55 \mathrm{e}^{0.041 t}$ & $F=124.26 \mathrm{e}^{0.04 t}$ & $F=124.24 \mathrm{e}^{0.036 t}$ & $F=125.56 \mathrm{e}^{0.033 t}$ & $F=131.48 \mathrm{e}^{0.032 t}$ \\
\hline & $\mathrm{R}^{2}$ & 0.85 & 0.8 & 0.78 & 0.84 & 0.64 \\
\hline & $\mathrm{Q}_{10}$ & 1.50 & 1.50 & 1.44 & 1.39 & 1.38 \\
\hline \multirow{3}{*}{ hummock } & Relation & $F=0.75 \mathrm{e}^{0.077 t}$ & $F=0.92 \mathrm{e}^{0.076 t}$ & $F=0.94 \mathrm{e}^{0.072 t}$ & $F=0.95 \mathrm{e}^{0.065 t}$ & $F=1.16 \mathrm{e}^{0.05 t}$ \\
\hline & $\mathrm{R}^{2}$ & 0.93 & 0.89 & 0.85 & 0.86 & 0.69 \\
\hline & $\mathrm{Q}_{10}$ & 2.16 & 2.131871 & 2.058546 & 1.917457 & 1.647073 \\
\hline \multirow{3}{*}{ hollow } & Relation & $F=1.23 \mathrm{e}^{0.08 t}$ & $F=1.19 \mathrm{e}^{0.086 t}$ & $F=1.18 \mathrm{e}^{0.078 t}$ & $F=1.24 \mathrm{e}^{0.068 t}$ & $F=1.28 \mathrm{e}^{0.076 t}$ \\
\hline & $\mathrm{R}^{2}$ & 0.76 & 0.82 & 0.82 & 0.81 & 0.8 \\
\hline & $\mathrm{Q}_{10}$ & 2.23 & 2.35 & 2.18 & 1.97 & 2.13 \\
\hline
\end{tabular}

\section{Discussion}

Greenhouse gas emission fluxes from peat bogs usually peak in summer $[15,19]$. Entering the growing season, the temperature gradually rises, and the precipitation increases. The combination of water and heat is conducive to the growth of plants, and the plants enter a period of vigorous growth. At the same time, the decomposition of soil organic matter accelerates with the strengthening of microbial activities in the soil, and the respiration of plants and soil microorganisms is enhanced, which in turn increases the $\mathrm{CO}_{2}$ emission flux of peat bog soil $[15,19]$. Therefore, the value of $\mathrm{CO}_{2}$ emission flux of peat bogs is the smallest when it just enters the growing season. As the temperature rises and precipitation increases, the $\mathrm{CO}_{2}$ emission flux reaches its peak in July. Thereafter, the $\mathrm{CO}_{2}$ emission flux decreases with the decrease of temperature and precipitation and the results of this study are consistent with it. In this paper, the seasonal variation of $\mathrm{CH}_{4}$ emission flux is consistent with that of $\mathrm{CO}_{2}$ (Figure 3), which is caused by changes in soil temperature [15, 20-21]. At the beginning of the growing season, the soil temperature is low. As time goes by, the soil temperature and the rate of soil organic matter degradation increases, and the oxidation-reduction potential decreases, which accelerates the growth of plants and increases the active carbon source substrate. The activity of $\mathrm{CH}_{4}$-producing bacteria eventually leads to an increase in soil $\mathrm{CH}_{4}$ emission flux, reaching a peak in the highest month of soil temperature, and then gradually decreasing [15, 20-21].

Previous studies have shown that soil $\mathrm{CO}_{2}$ emission flux is closely related to the change of water level. The permeability of the soil increases, which in turn increases the rate of organic matter degradation in the soil, when the water level decreases,. When the water level drops below the surface of the marsh soil, the amount of solar radiation received by the marsh soil increases, and the soil temperature rises, which can also accelerate the decomposition of organic matter in the soil and increase the $\mathrm{CO}_{2}$ emission flux in the soil. Therefore, the $\mathrm{CO}_{2}$ emission flux in depressions is lower than that of grassy hills [22-23], which is consistent with the results of this paper (Figure 3). In addition, the water level is also an important factor affecting the changes in soil $\mathrm{CH}_{4}$ emission flux [24]. The results of this study found that the $\mathrm{CH}_{4}$ emission flux of hollow is higher than that of hummocky. As the water level is low, the surface soil has a greater $\mathrm{CH}_{4}$ oxidation potential [25-27], and $\mathrm{CH}_{4}$ produced by $\mathrm{CH}_{4}$-producing bacteria is easy to produce. It is oxidized [24], which reduces the emission flux of $\mathrm{CH}_{4}$ emission flux. When the water level is high, the oxidation of $\mathrm{CH}_{4}$ weakens and the emission flux of $\mathrm{CH}_{4}$ increases [24].

\section{Conclusion}

During the growing season in 2020, the average $\mathrm{CO}_{2}$ emission flux from peat bogs in the Arak Lake Basin was $368.79 \pm 54.70 \mathrm{mg} \cdot \mathrm{m}^{-2} \cdot \mathrm{h}^{-1}$, which was significantly higher than the average $\mathrm{CO}_{2}$ emission flux of depressions (165.96 \pm 20.19 $\left.\mathrm{mg} \cdot \mathrm{m}^{-2} \cdot \mathrm{h}^{-1}\right)(n=5, p=0.001)$, the peaks of $\mathrm{CO}_{2}$ emission fluxes in hummocky and hollow all appeared in July, and the lowest values all appeared in May. The $\mathrm{CO}_{2}$ emission flux during the growth season of the hummocky was mainly affected by the soil temperature of $5 \mathrm{~cm}, 10 \mathrm{~cm}, 15 \mathrm{~cm}$ and $20 \mathrm{~cm}$, while the $\mathrm{CO}_{2}$ emission flux during the growth season of the hollow was mainly affected by the $5 \mathrm{~cm}$ soil temperature.

The average $\mathrm{CH}_{4}$ emission fluxes of hummocky were $1.78 \pm 0.27 \mathrm{mg} \cdot \mathrm{m}^{-2} \cdot \mathrm{h}^{-1}$, which was significantly lower than the average $\mathrm{CH}_{4}$ emission fluxes of hollow $\left(\mathrm{mg} \cdot \mathrm{m}^{-2} \cdot \mathrm{h}^{-1}\right)(n=5$, $p=0.007$ ), the peaks of $\mathrm{CH}_{4}$ emission fluxes from hummocky and hollow all appeared in July, and the lowest values all appeared in May. The $\mathrm{CH}_{4}$ emission flux during the growth season of the hummocky was mainly affected by the soil temperature of $5 \mathrm{~cm}, 10 \mathrm{~cm}, 15 \mathrm{~cm}$ and $20 \mathrm{~cm}$, while the $\mathrm{CH}_{4}$ emission flux during the growth season of the hollow was mainly affected by $5 \mathrm{~cm}, 10 \mathrm{~cm}, 15 \mathrm{~cm}, 20 \mathrm{~cm}$ and $30 \mathrm{~cm}$.

\section{Acknowledgements}

This research was funded by Foundation of Qinghai Province (Grant No. 2018-ZJ-972Q).

\section{References}

[1] Joosten H, Clarke D. Wise use of mires and peatlands. International mire conservation group, 2002.

[2] Fu G, Li K. Progress in the study on the relationship between global warming and wetland ecological system. Geographical Research, 2001, 20 (1): 120-128. (in Chinese with English abstract). 
[3] Solomon S, Qin D, Manning M, et al. IPCC 2007: climate change 2007: the physical basis. Contribution of Working Group I to the Fourth Assessment Report of the Inter governmental Panel on Climate Change. Cambridge: Cambridge University Press, 2007.

[4] IPCC. Working Group I contribution to the IPCC 5th Assessment Report "Climate Change 2013: The Physical Science Basis". 2013.

[5] Zhou Y, Guo D. Principal characteristics of permafrost in China Journal of Glaciology and Cryopedology, 1982, 4 (1): 1-19. (in Chinese with English abstract).

[6] Zhang $Z$. The formation characteristics of frozen-area bogs in China. Journal of Glaciology and Cryopedology, 1993, 15 (2): 225-229. (in Chinese with English abstract).

[7] Miao Y, Song C, Sun L, et al. Greenhouse gas emissions from different wetlands during the snow-covered season in Northeast China. Atmospheric Environment, 2012a, 62: 328-335.

[8] Miao Y, Song C, Wang X, et al. Growing season methane emission from a boreal peatland in continuous permafrost zone of Northeast China: Effects of active layer depth and vegetation. Biogeosciences, 2012b, 9: 4455-4464.

[9] Ye S, Krauss K W, Brix H, et al. Inter-Annual Variability of Area-Scaled Gaseous Carbon Emissions from Wetland Soils in the Liaohe Delta, China. Plos One, 2016, 11: e0160612.

[10] Yu X, Song C, Sun L, et al. Growing season methane emissions from a permafrost peatland of northeast China: Observations using open-path eddy covariance method. Atmospheric Environment, 2017, 153: 135-149.

[11] Zhang $\mathrm{F}$, Liu $\mathrm{A}, \mathrm{Li} \mathrm{Y}$, et al. $\mathrm{CO}_{2}$ flux in alpine wetland ecosystem on the Qinghai-Tibetan Plateau. Acta Ecologica Sinica, 2008, 28 (2): 453-462. (in Chinese with English abstract)

[12] Cao S, Cao G, Chen K, et al. Coupling relationships between alpine wetland ecosystem $\mathrm{CO}_{2}$ and vapor fluxes around the Qianghai Lake. Journal of Desert Research, 2016, 36 (5): 1286-1295. (in Chinese with English abstract)

[13] Hao Y B, Cui X Y, Wang Y F, et al. Predominance of Precipitation and Temperature Controls on Ecosystem $\mathrm{CO}_{2}$, Exchange in Zoige Alpine Wetlands of Southwest China. Wetlands, 2011, 31: 413-422.

[14] Pan B, Li J. Qinghai-Tibetan Plateau: a driver and amplifier of the global climatic change. Journal of Lanzhou University (Natural Sciences), 1996, 32 (1): 108-115. (in Chinese with English abstract).

[15] Zhou W, Cui L, Wang Y, et al. $\mathrm{CO}_{2}$ and $\mathrm{CH}_{4}$ emission fluxes from hummock and hollow in fen in Zoigê Plateau in 2014. Wetland Science, 2018, 16 (6): 693-699. (in Chinese with English abstract).
[16] Liu Y. Planning of Qinghai Dulan Arak Lake national wetland park. Forestry Construction, 2016 (3): 21-27. (in Chinese).

[17] Parish F, Sirin A, Chairman D, et al. Assessment on peatland, biodiversity and climate change: main report. Global Environment Center, Kuala Lumpur and Wetland International, Wageninge, 2008.

[18] Tong C, Wang W, Lei B, et al. Characteristics of temperature sensitivity of methane flux from the Shanyutan Tidal wetland in Min river estuary. Wetland Science, 2010, 8 (3): 240-248. (in Chinese with English abstract).

[19] Dong X, Chan Q, Li H, et al. Effects of climate change on permafrost greenhouse gas flux in alpine region of China. Soils and Crops, 2019, 8 (2): 178-185. (in Chinese with English abstract).

[20] Chang Y, Mu C, Peng W, et al. Characteristics of greenhouse gas emissions from seven swamp types in the permafrost region of Daxing an Mountains, northeast China. Acta Ecologica Sinica, 2020, 40 (7): 2333-2346. (in Chinese with English abstract).

[21] Xin G, Zhao Q, Yin H, et al. Effects of freeze- thaw process on the emission of two greenhouse gases from different forest soils in Changbai Mountain. Chinese Journal of Ecology, 2021, 40 (3): 644-653. (in Chinese with English abstract).

[22] Zhou W, Cui L, Wang Y, et al. Effects of drainage on the $\mathrm{CO}_{2}$ and $\mathrm{CH}_{4}$ emission fluxes in the Zoigê Plateau Marsh. China Environmental Science, 2019, 39 (7): 3040-3047. (in Chinese with English abstract).

[23] Wan Z. Effects of water level on $\mathrm{CO}_{2}$ and $\mathrm{CH}_{4}$ flux and soil microbial activity in Calamagrostis angustifolia marsh. Ecology and Environmental Sciences, 2013, 22 (3): 465-468. (in Chinese with English abstract).

[24] Wei D, Xu R, Tarchen T, et al. Revisiting the role of $\mathrm{CH} 4$ emissions from alpine wetlands on the Tibetan Plateau: Evidence from two in situ measurements at 4758 and $4320 \mathrm{~m}$ above sea level. Journal of Geophysical Research, 2015, 120: 1741-1750.

[25] Sun X, Mu C, Song C. Seasonal and spatial variations of methane emissions from montane wetlands in Northeast China. Atmospheric Environment, 2011, 45: 1809-1816.

[26] Wang J, Li Y, Li F. Emission fluxes of $\mathrm{CO}_{2}, \mathrm{CH}_{4}$, and $\mathrm{N}_{2} \mathrm{O}$ from artificial and natural reed wetlands in Bosten Lake. Acta Ecologica Sinica, 2018, 38 (2): 668-677. (in Chinese with English abstract).

[27] Liu H, Liu M, Liu L, et al. CH4 flux characteristics and influencing factors in six land use patterns in the Loess Plateau. Chinese Journal of Eco-Agriculture, 2018, 26 (7): 937-947. (in Chinese with English abstract). 